\title{
Pendampingan Dan Pelatihan Diversifikasi Pengolahan Ikan Bagi Ibu-Ibu Nelayan Di Pulau Sembilan Kabupaten Sinjai
}

\author{
Dian Safitri $^{1}$, Wira Yustika R ${ }^{2}$, Irmawanty ${ }^{3}$, Hilmi Hambali ${ }^{4}$ \\ ${ }^{1,2}$ Program Studi Pendidikan Biologi, Fakultas dan Ilmu Pendidikan, \\ Universitas Muhammadiyah Makassar \\ E-mail: Korespondensi: diansafitri@unismuh.ac.id
}

\begin{abstract}
Abstrak: Pengabdian kepada masyarakat dimaksudkan untuk melakukan edukasi atau transfer ilmu dari sumber informasi kepada penerima informasi. Program ini telah memberikan perubahan baik secara sosial mapun ekonomi dengan sasaran utama adalah kesejahteraan. Wilayah Pulau Sembilan merupakan salah satu wilayah yang terletak di Kabupaten Sinjai yang memiliki potensi daratan dan laut yang cukup besar. Sektor kelautan dan perikanan di wilayah ini dalam jangka pendek diketahui sebagai sektor yang mampu memberikan dampak terhadap kegiatan produksi dari sektor lain (Output Multiplier/OM) dan peningkatan pendapatan masyarakat (Income Multiplier/IM). Program pengabdian masyarakat yang telah dilakukan melibatkan ibu-ibu nelayan di Pulau Sembilan sebanyak 30 orang dan dibagi dalam 5 kelompok kecil yang didampingi tutorial. Ikan diolah menjadi berbagai produk diantaranya adalah bakso ikan, fish nugget dan abon ikan. Pendampingan dan pelatihan yang telah dilakukan menambah keyakinan masyarakat dalam meningkatkan pendapatannya (Income Multiplier/IM) sehingga dapat menopang ekonomi masyarakat Pulau Sembilan Kabupaten Sinjai.
\end{abstract}

\section{Kata Kunci: Pelatihan, Diversifikasi, Produk Olahan, Nelayan}

Abstract: Community service is intended to educate or transfer knowledge from information sources to recipients of information. This program has provided changes both socially and economically with the main target being welfare. The Sembilan Island region is one of the areas located in Sinjai Regency which has considerable land and sea potential. The marine and fisheries sector in this region in the short term is known as a sector that is able to have an impact on production activities from other sectors (Output Multiplier / OM) and increase in people's income (Income Multiplier / IM). The community service program that has been carried out involves 30 fishermen mothers in Pulau Sembilan and divided into 5 small groups accompanied by tutorials. Fish is processed into various products including fish balls, fish nuggets and shredded fish. The assistance and training that has been done have increased the community's confidence in increasing their income (Income Multiplier / IM) so that they can sustain the community's economy in Sembilan Island, Sinjai Regency. 


\section{Key Words: Training, Diversification, Processed Products, Fishermen}

Pulau Sembilan merupakan salah satu wilayah yang terletak di Kabupaten Sinjai dengan potensi hasil laut yang cukup besar. Salah satu hasil laut yang terdapat di wilayah tersebut adalah ikan yang oleh masyarakat hanya dijual dalam bentuk mentah atau diolah menjadi ikan asap. Ikan yang biasanya dijual ataupun diolah menjadi ikan asap adalah jenis cakalang, kerapu, dan jenis ikan tongkol. Ketiga ikan tersebut memiliki nilai gizi yang tinggi, namun belum mampu diolah secara baik oleh masyarakat setempat menjadi produk dengan nilai ekonomi yang tinggi. Olehnya itu, perlu dilakukan penyuluhan ataupun pelatihan tentang pemanfaatan ikan sebagai bahan dasar pembuatan produk makanan dengan melibatkan masyarakat wilayah Pulau Sembilan sebagai subyek pelatihan sehingga mereka memiliki pengetahuan dalam mengolah ikan. Selain itu, kegiatan ini berfokus kepada pemberdayaan masyarakat wilayah Pulau Sembilan, khususnya kaum ibu-ibu dan remaja putri yang lebih banyak menghabiskan waktu di rumah untuk dapat memiliki keterampilan (life skill) yang dapat mendukung peningkatan ekonomi keluarga (Rijal. M, 2016)

Wilayah Pulau Sembilan merupakan salah satu wilayah yang terletak di Kabupaten Sinjai yang memiliki potensi daratan dan laut yang cukup besar. Masyarakat wilayah Pulau Sembilan pada umumnya bermatapencaharian sebagai nelayan dan petani, selebihnya adalah pegawai pemerintahan dan wiraswasta. Masyarakat nelayan di dominasi oleh masyarakat yang bermukim di sekitar pesisir pantai dengan mengandalkan sistem konvensional dalam melaut, namun hasil tangkapan yang diperoleh cukup besar sehingga di wilayah Pulau Sembilan sangat layak dilakukan penyuluhan ataupun pelatihan dalam pengolahan ikan pasca tangkap menjadi produk dengan nilai jual yang tinggi.

Tingginya aktivitas masyarakat nelayan di wilayah Pulau Sembilan menyebabkan produksi ikan, khususnya jenis kerapu, cakalang, dan tongkol sangat banyak dan menjadi salah satu komoditas ekspor di wilayah tersebut. Ikan tuna diekspor beberapa daerah di luar Kabupaten Sinjai, seperti: Jakarta, Surabaya, Bandung, dan beberapa daerah lainnya di Indonesia, bahkan ekspor ikan kerapu dan tenggiri sampai ke manca negara, seperti: Australia, belanda, dan lainnya. Selain sebagai nelayan, masyarakat Pulau Sembilan juga bekerja sebagai pegawai pemerintahan, dan wiraswasta. Umunya yang bekerja sebagai nelayan adalah kaum pria, sehingga muncul permasalah ketimpangan kesibukan antara kaum laki-laki dan perempuan. Kaum perempuan, khususnya ibu-ibu lebih banyak menghabiskan waktu di rumah bersama dengan keluarganya dan hanya sebagian kecil yang bekerja sebagai pegawai ataupun membantu suami dalam mempersiapkan kebutuhan melaut.

Ibu-ibu yang banyak menghabiskan waktu di rumah terkadang merasa bosan ataupun jenuh dan mereka mengharapkan adanya kesibukan yang bisa bermanfaat untuk 
kesejahteraan keluarganya (Rijal. M, 2016). Hasil wawancara dengan 20 orang informan (Mei, 2019) diperoleh data bahwa 17 orang mengharapkan adanya kesibukan yang sifatnya menambah pengetahuan ataupun keterampilan mereka, dan 3 orang tidak memberikan jawaban apapun. Tingginya minat masyarakat Wilayah Pulau Sembilan, khususnya kaum ibu-ibu untuk maju merupakan alasan bagi kami untuk memberikan dampingan sekaligus pengetahuan tentang bagaimana cara mengolah ikan menjadi beberapa produk yang layak jual.

Hasil sebaran angket kepada 20 orang informan (Mei, 2019), diperoleh data bahwa selama ini, mereka belum pernah mendapatkan pelatihan ataupun memperoleh pengetahuan tentang bagaimana cara mengolah ikan. Mereka hanya tahu mengolah ikan menjadi menu komsusi sehari-hari, seperti ikan kuah ataupun oseng-oseng. Karena minimnya pengetahuan dan tidak adanya keterampilan dalam mengolah ikan, membuat mereka jenuh untuk membuat produk yang kurang variatif, sehingga sebagian besar ikan akan dikeringkan sebagai bahan cadangan ikan saat musim ombak tiba. Hasil angket juga memberikan informasi bahwa 20 informan mengharapkan sekali adanya pelatihan pengolahan ikan, karena di wilayah mereka bahan baku tersebut banyak dan belum termanfaatkan secara optimal.

\section{METODE PENELITIAN}

Program pengabdian masyarakat yang akan dijalankan akan melibatkan ibu-ibu nelayan di Pulau Sembilan yang merupakan subyek yang kurang mendapatkan perhatian dari berbagai pihak, sehingga hal ini dapat berdampak terhadap kesetaraan gender, khususnya dalam bidang kesejahteraan dan penghidupan yang layak bagi kaum perempuan. Meskipun kodratnya kaum wanita adalah menjadi istri dan ibu bagi anakanaknya, bukan berarti mereka harus banyak tinggal di rumah tanpa melakukan kerja ataupun aktivitas yang mereka inginkan. Pengabdian ini bersifat pendampingan kepada kaum ibu-ibu nelayan agar mereka memiliki pengetahuan tentang bagaimana memanfaatkan ikan yang banyak terdapat di wilayah mereka untuk dijadikan sebagai produk olahan dengan nilai gizi serta jual yang cukup tinggi.

Selain pendampingan, pengabdian ini akan memberikan skill atau keterampilan kepada kaum ibu-ibu nelayan di Pulau Sembilan untuk melakukan diversifikasi olahan ikan, seperti: dibuat menjadi kerupuk, nugget, otak-otak, atau dapat juga dibuat menjadi dendeng sehingga produk yang dihasilkan lebih tahan lama dan bisa menjadi cikal bakal produk unggulan selain ekspor daging ikan. Adanya pengabdian masyarakat ini, diharapkan agar kondisi dampingan, khsusnya kaum ibu-ibu nelayan akan lebih baik dalam hal pengetahuan dan keterampilan dalam mengolah limbah ikan dan diharpakan dapat membantu perekonomian keluarga tanpa meninggalkan tugas utamanya sebagai seorang istri dan ibu bagi anak-anak mereka. 
Hal pertama yang dilakukan adalah melakukan survey tentang ketersediaan sumber daya alam dan sumber daya manusia. Hasil survey awal menunjukkan bahwa di Pulau Sembilan banyak terdapat ikan tuna, cakalang, dan tongkol yang oleh masyarakat belum terolah secara maksimal. Setelah melakukan survey sumber daya alam lokal, maka dilakukan survey sumber daya manusia yang akan dijadikan sebagai masyarakat sasaran pendampingan dan pelatihan dalam mengolah ikan menjadi aneka jenis produk makanan yang bernilai gizi dan ekonomi tinggi. Setelah survey sumber daya alam lokal dan sumber daya manusia selesai dilakukan, maka langkah selanjutnya adalah melaksanakan strategi untuk mencapai kondisi yang diharapkan. Strategi yang pertama dilakukan adalah dengan mengajar ibu-ibu nelayan untuk bergabung dalam program pengabdian ini, yaitu mereka akan dibentuk menjadi kelompok binaan yang berjumlah 30 orang dan menunjuk salah seorang diantara mereka sebagai ketua kelompok. Setelah kelompok terbentuk, maka akan dilakukan penyuluhan tentang manfaat ikan dalam bidang kesehatan maupun sebagai bahan dasar dalam pembuatan aneka jenis makanan olahan yang bernilai gizi dan ekonomi.

Setelah penyuluhan selesai, maka dilakukan demonstrasi terbimbing dan praktikum untuk memberikan keterampilan kepada para peserta latihan dalam mengolah limbah ikan menjadi aneka produk makanan, dan peserta pelatihan akan dibagi menjadi 5 kelompok kecil yang nantinya akan didampingi oleh tutorial (pendamping praktikum) dalam membuat sampai mengasilkan produk. Setelah produk dihasilkan, maka selanjutnya dilakukan pengujian keamanan pangan yang dilakukan oleh tenaga analis laboratorium Biologi dan Kimia, dan dilakukan pendampingan hingga pengemasan produk. Setelah produk dikemas, maka strategi selanjutnya adalah membantu dalam pengujian kelayakan konsumsi produk. Program pengabdian ini tidak akan berjalan dengan baik jika tidak ditunjang oleh pihak-pihak yang berkompeten dalam memberikan pendampingan dan pelatihan kepada masyarakat Pulau Sembilan. Pihak utama yang terlibat adalah pihak pemberi bantuan dana program pengabdian kepada masyarakat yaitu Lembaga Pengembangan Penelitian dan Pengabdian Kepada Masyarakat (LP3M) Universitas Muhammadiyah Makassar Tahun Anggaran 2019. Selain itu, Pemerintah wilayah dan masyarakat Pulau Sembilan yang memberikan fasilitas berupa tempat ataupun peralatan yang dibutuhkan selama proses pengabdian berlangsung.

Tim yang akan terlibat dalam program pengabdian kepada masyarakat ini memiliki pengalaman dalam bidang pemanfaatan limbah, khususnya limbah organik (Tim ini beranggotakan 3 orang yang masing-masing berkompeten dalam bidang pendidikan dan gizi pangan. Ketua peneliti (Wira Yustika Rukman, S. Farm., Apt., M.Kes) merupakan Dosen pada Program Studi Pendidikan Biologi yang telah memiliki pengalaman dalam mengolah bahan pangan, termasuk limbahnya, sekaligus sebagai tenaga analis laboratorium Biologi dan Kimia dengan segudang pengalaman terkait uji keamanan pangan baik secara kualitatif maupun kuantitatif. Dian Safitri, S.Pd., M.Pd 
(anggota 1) yang juga merupakan dosen pada Program Studi Pendidikan Biologi, telah memiliki pengalaman dalam kegiatan penyuluhan pengolahan berbagai bahan pangan melalui program pengabdian masyarakat dan telah membimbing beberapa mahasiswa yang meneliti tentang pengolahan bahan pangan hingga limbahnya untuk mengatasi pencemaran lingkungan. Irmawanty, S.Si., M.Si dan Hilmi Hambali, S.Pd., M.Kes (Anggota 2 dan 3), juga merupakan Dosen yang telah mengikuti berbagai pelatihan pengabdian kepada masyarakat berbasis lingkungan, dan mereka memiliki pengetahuan dan keterampilan dalam mengolah ikan menjadi produk dengan nilai tambah yang tinggi.

\section{HASIL DAN PEMBAHASAN}

Pulau Persatuan merupakan salah satu desa yang ada di kecamatan pulau Sembilan kabupaten Sinjai. Masyarakat pulau Persatuan Pulau Persatuan 100\% beragama Islam dengan matapencaharian nelayan. Hasil laut yang potensial di pulau Persatuan adalah ikan dan rumput laut dengan jenis ikan yang paling dominan adalah tuna, cakalang, dan tongkol.

Hasil laut yang melimpah berupa ikan merupakan potensi yang besar untuk dikembangkan dalam menopang perokonomian dan meningkatkan kesejahteraan masyarakat pulau Persatuan. Tingginya produksi perikanan di pulau Persatuan, menyebabkan rendahnya harga ikan dan berdampak terhadap menurunnya pendapatan masyarakat, namun saat produksi ikan menurun maka harga ikan menjadi mahal dan terkadang masyarakat kesulitan dalam memperoleh ikan sebagai bahan konsumsi keluarga. Ikan sebagai hasil tangkap masyarakat Pulau Persatuan umumnya hanya dijual dalam bentuk ikan segar dan kadang-kadang sisanya dikeringkan atau dibuat ikan asap. Namun kendala yang muncul adalah jarak tempuh penjualan ke kota Sinjai yang cukup jauh sehingga biaya transportasi lebih mahal dibandingkan dengan harga jual ikan. Jika ikan diolah menjadi ikan kering ataupun asap, maka muncul rasa bosan bagi konsumen karena tidak ada variasi dalam produk olahan ikan. Variasi produk olahan ikan sangat penting untuk meningkatkan nilai jual dan standar selera konsumen sehingga tidak bosan dengan produk yang sudah ada sebelumnya (Rijal. M, 2016).

Di Pulau Persatuan, masyakarat belum pernah mendapatkan pelatihan ataupun penyuluhan tentang pengolahan ikan pasca tangkap menjadi produk olahan selain ikan asap dan ikan kering. Ikan merupakan bahan pangan dengan kandungan gizi yang sangat tinggi, khususnya kandungan protein yang sangat baik untuk pertumbuhan dan kecerdasan. Kebanyakan anak-anak di Indonesia sangat malas makan ikan dalam bentuk aslinya, padahal Indonesia terkenal sebagai lumbung ikan dunia. Kurangnya minat makan ikan anak-anak Indonesia, mengakibatkan adanya penderita gizi protein dan penghambatan pertumbuhan. Ikan dapat diolah menjadi berbagai macam produk olahan seperti: bakso ikan, nugget ikan dan abon ikan dengan nilai gizi serta jual yang tinggi. 


\section{Bakso Ikan}

Variasi bakso kini semakin menarik saja, jika biasanya bakso yang dinimati diolah dengan baik dari daging sapi atau daging ayam dan ikan tanpa menggunakan isian tertentu, kini banyak pedagang bakso yang menjual bakso sapi atau bakso daging ayam dengan menambahkan isian tertentu, seperti bakso urat yang diisi dengan irisan tendon atau urat serta daging tetelan kasar, bakso bola tenis atau yang dikenal sebagai bakso telur yang diisi dengan telur ayam rebus, bakso gepeng yang bentuknya pipih, bakso ikan yang diolah dengan menggunakan daging ikan, dan yang paling lengkap adalah bakso khas Malang yang mana dihidangkan dengan menggunakan mie kuning, siomay, tahu, serta pangsit goreng dan berbagai hidangan bakso unik lainnya. Bola-bola daging yang lebih kita kenal dengan bakso ada beberapa macam. Ada bakso dari daging sapi, daging ayam, daging ikan, udang, atau cumi. Setiap bakso memiliki warna dan tekstur yang berbeda. Jenis dan kualitas ikan sangat menentukan hasil bakso ikan yang kita buat. Pilih ikan bertekstur kenyal dan segar. Contohnya ikan tenggiri yang gepeng. Ikan tenggiri yang bulat kurang lengket teksturnya sehingga hasil baksonya tidak sebagus ikan tenggiri yang gepeng.

Anak-anak dan anggota keluarga lain suka makan bakso, tetapi bosan dengan bakso daging sapi yang biasanya. Ingin mencoba resep masakan bakso yang spesial dengan citarasa uang unik dan kandungan gizi yang komplit? Kalau iya, ini saatnya kita akan mencoba resep membuat bakso ikan kuah atau juga bisa disebut fish ball. Apalagi saat ini harga daging sapi lokal yang tidak menentu dan cenderung terus naik tinggi. Saatnya kita mencari alternatif bahan dasar lain untuk membuat hidangan kegemaran keluarga ini. Untuk ikan yang digunakan untuk membuat resep bakso ikan ini bisa disesuaikan sesuai selera, seperti ikan tengiri, ikan lele, ikan kakap, ikan tuna atau jenis lainnya. Cara membuat bakso ikan kuah ini cukup mudah dan mirip sekali dengan resep membuat bakso daging yang sudah pernah kita berikan sebelumnya. Resep bakso memang merupakan salah satu masakan yang banyak digemari oleh masyarakat Indonesia. Hampir di semua wilayah dengan mudah kita temui penjual bakso yang enak dan lezat. Tapi memang pada umumnya yang dijual tersebut adalah bakso daging sapi dengan kuah bakso yang sedap dan segar. Nah untuk itu kali ini kita akan membuat resep bakso ikan dengan kuah yang beda dari resep yang biasanya. Cara membuat bakso ikan ini cukup mudah dan lebih praktis daripada resep bakso sapi biasanya.

Cara membuat bakso atau fish ball memang tidak semudah membuat resep masakan Indonesia lainnya. Ada beberapa tips khusus yang harus diperhatikan supaya resep bakso ikan kuah yang kita buat nanti hasilnya sempurna dan rasanya enak dan lezat. Yang paling utama tentu bahan utama resep bakso ikan yang digunakan harus benar-benar ikan segar dan kualitasnya baik. Hampir semua daging ikan yang berwarna putih, speerti ikan patin, ikan kerapu, ikan tengiri, ikan tuna bahkan ikan lele pun bisa dengan mudah kita proses menjadi bakso ikan yang enak dan lezat. Yang paling penting daging ikan 
tersebut harus segar dan mempunyai tekstur yang kenyal dan tidak lembek supaya bakso ikan kuah yang kita bikin nanti hasilnya juga menjadi kenyal dan nikmat disantap. Satu lagi yang paling penting adalah daging ikan yang digunakan harus benar-benar bersih dari duri ikan.

Selain ikan sebagai bahan utama dalam resep masakan ikan ini, tepung sagu atau tepung tapioka yang digunakan harus benar-benar bersih dari kotoran. Tepung yang digunakan harus disaring terlebih dahulu sampai halus. Karena resep bakso ikan ini sangat sensitif dengan suhu, untuk itu ikan yang digunakan harus dalam kondisi dingin. Selain itu kita nanti tidak menggunakan air untuk membuat adonan resep bakso dari bahan ikan ini. Sebagai gantinya es yang diserut supaya suhu adonannya tetap terjaga. Untuk menjaga kekenyalan pentol baksonya, setelah bakso matang sebaiknya ditiriskan saja dan jangan terlalu lama direbus supaya tekstur nya tetap kenyal dan empuk.

\section{Fish Nugget}

Nugget adalah nama makanan olahan yang terbuat dari bahan dasar tepung, daging ikan tenggiri dan juga bahan pelengkap lainnya. Untuk membuat nugget, tidak harus menggunakan daging ikan tetapi bisa juga dengan daging ayam. Akan tetapi, resep yang akan kami bagikan kali ini adalah nuuget ikan tenggiri. Nugget ikan tenggiri memiliki rasa yang enak dan gurih juga memiliki bau yang khas dari ikan. Makanan ini dapat dijadikan sebagai lauk yang banyak disukai oleh anak-anak karena rasanya yang gurih. Makanan ini sudah banyak tersedia dimana-mana terutama di minimarket atau supermarket terbesar. Untuk memilih jenis nugget yang lebih enak dan lebih sehat, lebih baik membuat nugget hasil olahan tangan sendiri karena dapat terjamin kebersihannya. Berikut adalah proses pembuatannya.

\section{Abon Ikan}

Abon ikan adalah produk yang memadukan beberapa proses seperti perebusan/pengukusan, penambahan bumbu-bumbu dan penggorengan. Abon ikan mempunyai tekstur yang sangat lembut dan rasa yang guruh, sangat cocok untuk laut atau teman makan roti dan dijadikan makanan kecil. Berbagai jenis ikan yang sering dijadikan bahan dasar abon ikan adalah ikan cakalang dan ikan tuna.

\section{KESIMPULAN}

Pendampingan dan pelatihan pembuatan bakso ikan, fish nugget, dan abon ikan bagi masyarakat nelayan di desa persatuan kecematan pulau Sembilan kabupaten Sinjai berjalan dengan baik dan para peserta sangat antusias dalam mengikuti pelatihan tersebut dari awal sampai akhir kegiatan. Para peserta mendapatkan pengetahuan baru dalam mengolah ikan selain menjadi ikan kering dan ikan asap. Setelah mereka mengetahui bahwa ikan tuna, tongkol, dan cakalang dapat dibuat menjadi bakso ikan, fish nugget, dan abon ikan, mereka tidak lagi berfokus untuk melakukan pengasapan ataupun pengeringan, bahkan beberapa dari peserta pelatihan swadaya membuat sendiri bakso ikan, fish nugget, 
dan abon ikan untuk dijual meskipun masih terbatas dikalangan warga desa Pulau Persatuan dan pulau lain di Kecamatan Pulau Sembilan.

\section{SARAN}

Ikan yang merupakan hasil tangkapan nelayan di pulau Persatuan Kecamatan Pulau Sembilan salah satu bahan makanan yang mudah busuk sehingga harus diolah menjadi produk olahan yang tahan lama dan memiliki nilai ekonomi yang tinggi. Ibu-ibu di pulau persatuan harus menerapkan ilmu yang telah diperoleh pada saat pendampingan dan pelatihan diversifikasi produk olahan ikan, bukan hanya membuat bakso ikan, fish nugget, dan abon ikan tetapi dapat juga membuat keripik ikan.

\section{DAFTAR PUSTAKA}

Afonso, Claudia., Lourenco, Helena Maria., Cardoso Carlos., Bandarra, Narcisa Maria., Carvalho, Maria Luisa., Castro, Matilde., Nunes, Maria Leonor. (2013). From Fish Chemical Characterisation to the Benefit - Risk Assesment - Part A. Food Chemistry. 137. 99 - 107.

Clucas, I.J. and Ward, A. R. (1996). Post-Harvest Fisheries Development: A Guide to Handling, Preservation, Processing and Quality. Natural Resources Institute.

Hadiroiyoto, Suwendo. (1993). Teknologi Pengolahan Hasil Perikanan, Jilid I. Yogyakarta: Liberty. Hlm.56

Murray, J \& Burt, J. R. (2001). The composition of Fish. Torry Advisory Note no 38. Torry Research Station. Aberdeen http://www.fao.org.

Hadiwiyoto, Suwedo. (1993). Teknologi Pengolahan Hasil Perikanan. Yogyakarta: Liberty. $275 \mathrm{hlm}$.

Ilyas, Sofyan. (1983). Teknologi Refrigerasi Hasil Perikanan Jilid I. Jakarta: CV Paripurna. Hlm.35

Isabel Martinez-Valverde, Maria Jesus Periago, Marina Santaella, Gaspar Ros. (2000). The Content and Nutritional Significance of Minerals on Fish Flesh in the Presence and Absence of Bone. Food Chemistry 71, 503 - 509.

Jabeen Farhat and Chaudry, Abdul Shakoor. (2011). Chemical Composition and Fatty Acid Profiles of Three Freshwater Fish Species. Food Chemistry 125. 991-996.

Ladrat, C., Verrez-Bagnis, V., Noel, J., and Fleurence, J. (2003). In Vitro Proteolysis of Myofibrillar and Sarcoplasmic Protein of White Muscle of Sea Bass (Dicentrarchus labrax L): Effect of Chathepsine B, D and L. Food Chemistry. 81, 517 - 525.

Marcela Veles Alaves, Lia C, Mendez Rodriguez, Juan A. De Anda Montanez, C. Humberto Meija, Felipe Galvan Magana, Tania Zenteno-Savin. (2014). Vitamin C and E Concentration in Muscle of Elasmobranch and Teleost Fishes. Comparative Biochemistry and Physiology, Part A. 170 (2014) 26-30. 
Moelyanto, R. (1992). Pengawetan dan Pengolahan Hasil Perikanan. Jakarta: Penebar Swadaya. Hlm.27-29

Nurnadia, A.A., Azrina, A. and Amin, I. (2011). Proximate Composition and Energetic Value of Selected Marine Fish and Shellfish From the West Coast of Peninsular Malaysia. International Food Research Journal 18 : 137 - 148.

Ricci, Ignacio. (2011). Penanganan Ikan di Kapal (Hendling) Alat Tangkap dan Pengawet Ikan. Dalam http://www.perikanan.web.id

Rijal, M. (2016). PENGOLAHAN DAN PENINGKATAN KADAR PROTEIN FISH NUGGET BERBAHAN DASAR LIMBAH IKAN DENGAN PEMBERIAN EKSTRAK KULIT NANAS. Biosel (Biology Science and Education): Jurnal Penelitian Sains dan Pendidikan, 5(1), 84-92.

Rijal, M. (2016). Diversifikasi Produk Olahan Ikan Bagi Ibu-Ibu Nelayan Di Dusun Mamua Kabupaten Maluku Tengah. Biosel: Biology Science and Education, 6(2), 159-170.

Rijal, M. (2016). Analisis Kandungan MPN dan ALT Total Pada Fish Nugget Berbahan Dasar Limbah Ikan. Biosel: Biology Science and Education, 5(2), 144-151.

Rodrigues, Nuria-Rubio., Beltran, Sagrario., Jaime, Isabel., M de Diego, Sara., Sanz, Maria Teresa., and Carballido, Jordi Rovira. (2010). Production of Omega 3 Polyunsaturated Fatty Acid Concentrates. Review. Innovative Food Science and Emerging Technologies. 11. 1-12.

Seadragon. (2010). Pendinginan ikan dengan menggunakan es balok. Dalam Pendinginan-ikan-dengan-menggunakan-es.html

Vareltzis, K. (2000). Fish Protein From Unexploited and Undeveloped Sources. In G. Doxastakis \& V. Kiosseouglou (Eds), Novel Macromolecules in Food Systems. Amsterdam Elsevier. (pp. 133-159). 